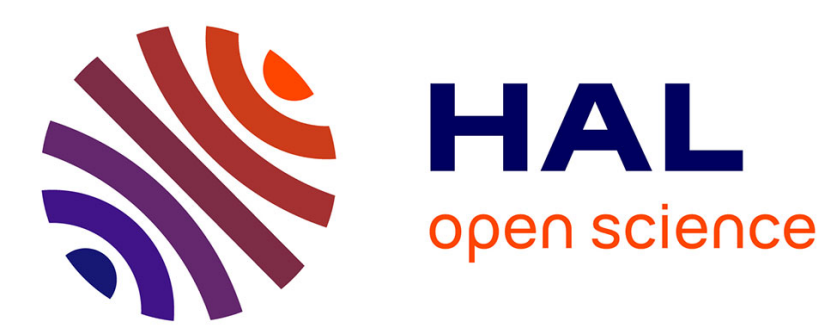

\title{
Michael Drayton's early career: reconsidering the Petrarchism of Ideas Mirrour (1594)
}

\author{
Rémi Vuillemin
}

\section{To cite this version:}

Rémi Vuillemin. Michael Drayton's early career: reconsidering the Petrarchism of Ideas Mirrour (1594). Studies in Philology, 2021. hal-03230461

\section{HAL Id: hal-03230461 \\ https://hal.science/hal-03230461}

Submitted on 19 May 2021

HAL is a multi-disciplinary open access archive for the deposit and dissemination of scientific research documents, whether they are published or not. The documents may come from teaching and research institutions in France or abroad, or from public or private research centers.
L'archive ouverte pluridisciplinaire HAL, est destinée au dépôt et à la diffusion de documents scientifiques de niveau recherche, publiés ou non, émanant des établissements d'enseignement et de recherche français ou étrangers, des laboratoires publics ou privés. 


\section{Michael Drayton's early career: reconsidering the Petrarchism of Ideas Mirrour (1594)}

Eum. There was neuer any so peeuish to imagin the Moone eyther capable of affection, or shape of a Mistris: for as impossible it is to make loue fit to her humor which no man knoweth, as a coate to her forme, which continueth not in one bignesse whilst she is measuring. Cease of Endimion to feede so much upon fancies. That melancholy blood must be purged, which draweth you to a dotage no lesse miserable then monstrous. ${ }^{1}$

In the very first lines of Lyly's Endimion, the Man in the Moone (1591), Eumenides thus admonishes his friend Endimion, who just declared that he was in love with the moon. His preposterous infatuation, however, comes to be perceived rather differently by both Eumenides and the spectators when Cynthia herself appears on stage in act 3, scene 1, and expresses her wish to find a way of rousing Endimion from the deep sleep to which he has succumbed, before giving him her blessing in act 5, scene 3. While the scenes of Elizabethan and Jacobean playhouses abounded with ridiculous lovers who expressed their adoration through hyperbolic language and Petrarchan conceits, Lyly's play (a "notorious enigma" yielding itself to a variety of allegorical and political interpretations, according to Robert S. Knapp) rehabilitates Endimion's yearnings. ${ }^{2}$ To a certain extent, Eumenides's words mirror the emphasis that the critical tradition has laid on the ridiculous lovers not just in drama, but also in sonnet sequences. As Gordon Braden insisted two decades ago, Elizabethan sonnets and English Petrarchism have long been read according to the "parody theory," which tends toward oversimplification. ${ }^{3}$ The consequence of this theory (fortunately not favored by all critics) was that the sonnet sequences (with the exception of the "parodic" ones, written by poets such as Shakespeare or Sidney) were seen as naïve, idealizing literary ventures suffused with hyperbolic vocabulary loosely based on "Petrarchism," a term sometimes misunderstood as a synonym of "Neoplatonism."

Thomas P. Roche Jr, in his Petrarch and the English Sonnet Sequences (1989), crucially revised such assumptions, claiming that the influence of Petrarch's Augustinianism needed to be taken into account. He contended that the speakers of most Elizabethan sonnet sequences should not be the object of sympathy: the sequences conveyed a moral perspective by negative example, showing the pitfalls into which the lover tumbled. It was therefore necessary to stop

\footnotetext{
${ }^{1}$ John Lyly, Endimion, the Man in the Moone (London: I.Charlewood for the widow Broome, 1591), Sig.B $\mathrm{B}^{\mathrm{r}-\mathrm{v}}$.

2 Ridiculous lovers can be found, of course, in Shakespearean drama, but also in plays written by other dramatists well into the seventeenth century. See Guillaume Coatalen's "Sonnet-mongers on the early modern stage," in The Early Modern English Sonnet: Ever in Motion, ed. Rémi Vuillemin, Laetitia Sansonetti, and Enrica Zanin, The Manchester Spenser (Manchester: Manchester University Press, forthcoming). On the problems of interpretation posed by Lyly's Endimion, see Robert S. Knapp “The Monarchy of Love in Lyly's 'Endimion'," Modern Philology 73, 4,1 (May 1976): 353-367.

${ }^{3}$ Gordon Braden, "Shakespeare's Petrarchism," in Shakespeare's Sonnets: Critical Essays, ed. James Schiffer (New York: Garland Publishing, 1999), 163-83.
} 
"patronizing" the sonnet sequence and to recognize that the reader was not to identify with the lovers speaking in them, but, on the contrary, was meant to perceive their "narcissistic selfindulgence."4 This went against much earlier criticism and introduced some complexity in the way Petrarchism was understood, a complexity further explored in the works of such scholars as William J. Kennedy or Heather Dubrow. ${ }^{5}$ Interestingly, it also aligned the speakers of the sonnet sequences with the puling lovers of Elizabethan drama, showing that such poetic collections should not be reduced to unequivocal praise.

Despite his contention that the love sonnet sequences of the 1590 s taught by negative example, Roche made an exception for Michael Drayton, who, he believed, wrote "about divine love under the metaphor of human love." In Drayton's case, it was indeed difficult to maintain his theory, especially for the early Ideas Mirrour (1594), a sequence in which the praise of the beloved is particularly vibrant. This makes it a very good testing ground for Roche's theory, and more generally for the revaluation of Petrarch's influence upon the English sonnet sequence that has been under way over the past decades. ${ }^{7}$ A recent monograph claims that Roche's theory can in fact be applied to Drayton's first sonnet sequence: it contends that the attempt at spiritual elevation in Ideas Mirrour fails, resulting in the questioning of the very language of praise. ${ }^{8}$ However, it does not explain how such an interpretation would agree with what is known of Drayton's works, and especially his early career. The following pages will examine Roche's theory and the exception he makes for Drayton. It will attempt to reconcile recent interpretations of Ideas Mirrour with what we know about his other early works, especially Idea. The Shepheards Garland (1593) and Endimion and Phoebe. Ideas Latmus (1595). I want to convey a sense of the elaborateness of the critically neglected Ideas Mirrour and how it fits within the bigger picture of early modern English sonneteering. By doing so, I hope to improve our understanding of Drayton's early career in the 1590s, which is not as well-known as his career as a leading Spenserian in the 1600s and 1610s, and perhaps most importantly, to make a contribution to our

\footnotetext{
${ }^{4}$ Thomas P. Roche Jr, Petrarch and the English Sonnet Sequences (New York: AMS Press, 1989), 8.

5 See for instance the following seminal studies: Heather Dubrow, Echoes of Desire: English Petrarchism and its Counterdiscourses (Cornell: Cornell University Press, 1995); William J. Kennedy, Authorizing Petrarch (Cornell: Cornell University Press, 1994) and The Site of Petrarchism: Early Modern National Sentiment in Italy, France and England (Baltimore: Johns Hopkins University Press, 2003).

${ }^{6}$ Roche, Petrarch and the English Sonnet Sequences, 277.

7 Drayton published Ideas Mirrour in 1594. The sequence was then re-named Idea and altered in five different editions first published respectively in 1599, 1600, 1602, 1605, and 1619. Considering that twenty-two sonnets disappeared and that twenty-eight others were added between 1594 and 1599, I consider Ideas Mirrour and Idea as two separate works. Important works on the influence of Petrarch in England other than those already cited include Jackson Campbell Boswell and Gordon Braden, Petrarch's English Laurels, 1475-1700, A Compendium of Printed References and Allusions (Farnham: Ashgate, 2012); Gordon Braden, "Shakespeare's Petrarchism"; William J. Kennedy, Petrarchism at Work: Contextual Economies in the Age of Shakespeare (Cornell: Cornell University Press, 2016).

${ }^{8}$ Rémi Vuillemin, Le Recueil pétrarquiste à l'ère du maniérisme : poétique des sonnets de Michael Drayton, 1594-1619 (Paris: Honoré Champion, 2014), 147-57, 165-228, 395-404, 451-9, and 483-500.
} 
knowledge of the intricacies of English Petrarchism. The notion of Petrarchism can encapsulate a wide variety of literary processes, ranging from the direct imitation of Petrarch's language and poetic project to the use of a language of praise (only partly similar to Petrarch's, and disconnected from his poetic aims) inherited from generations of imitators of the Tuscan poet, and from the imitators of these very imitators. I wish to contend that Drayton's poetic endeavor in Ideas Mirrour is closer to Petrarch's than has been claimed thus far, and that approaching it requires understanding the articulation of Petrarchism and Neoplatonism (two terms that are not unconnected, but that are not synonyms) in his sequence.

\section{Drayton's early career}

Hailed half a century ago as one of the leading Spenserians, ${ }^{9}$ Michael Drayton has been very much a household name among early modern scholars of English literature for the past few decades. Though he is far from being the most studied Elizabethan or Jacobean author, it has become customary to refer to his works-partly due to the generic and thematic breadth of his poetic writing. ${ }^{10}$ Drayton's sonnets have earned their fair share of commentary, and have even on occasion been used as the starting point of whole books on the early modern lyric. ${ }^{11}$ Anyone having some familiarity with Draytonian criticism, however, is likely to notice a recurrent pattern: the works written and published in the second part of his career (i.e., in the first two decades of the seventeenth century) have been brought to the fore, and the earlier works (except perhaps Englands Heroicall Epistles) have remained somehow neglected. Jean Brink was right to point out that Drayton's work "has been approached as an Elizabethan survival rather than a Jacobean critique." ${ }^{\prime 2}$ While Brink wished to insist on the way Drayton evolved into a satirist, I would like to underline the paradox in the notion of "Elizabethan survival." If Drayton has been recognized as a major Elizabethan poet, it is as one whose works belatedly bloomed during the Jacobean age, and as the leader of a group of nostalgic poets who came to represent regret for the Elizabethan

\footnotetext{
${ }^{9}$ Joan Grundy, The Spenserian Poets: A Study in Elizabethan and Jacobean Poetry (London: Edward Arnold, 1969).

${ }^{10}$ For a list of works on Drayton up to 1980, see James L. Harner, Samuel Daniel and Michael Drayton, A Reference Guide (Boston: G.K. Hall \& co, 1980). Since then, the only major reassessment of Drayton's career as a whole has been Jean R. Brink's Michael Drayton Revisited (Boston: Twayne Publisher, 1990). It is not possible here to list the numerous articles and book chapters that have been published on Drayton's works since the 1980s. Though Drayton's complaints, pastorals and "nymphals" have attracted much attention, it is perhaps Englands Heroicall Epistles, and, most importantly, Poly-Olbion, which have been analyzed most often. Drayton's poetry has been used to raise a wide range of issues, from the writing of history and nationalism to Ovidian imitation, from gender to ecocriticism, to name but a few.

11 See Christopher Warley, Sonnet Sequences and Social Distinction in Renaissance England (Cambridge: Cambridge University Press, 2005).

12 Brink, Michael Drayton Revisited, 136.
} 
era in the 1610s. ${ }^{13}$ In other words, while his works produced in the Jacobean age have tended to be analyzed (at least until the late 1980s, when Brink was writing her work) as Elizabethan literature, his early works, those produced in the 1590s (and even more significantly so in the first half of the 1590s) have received little critical attention.

In the case of Drayton's sonnets, the early Ideas Mirrour (1594) has been largely ignored by scholars, if not discarded as an uninteresting literary work. The most obvious reason for such neglect is that the sequence was revised in depth and published in 1599 as Idea, which is also the title of new versions of the sequence published in 1600, 1602, 1605, and 1619. Scholars do not really seem to have felt the need to see the changes from one version to the next as anything other than improvements, assuming that the very first version was necessarily the least accomplished one-thus adopting a teleological pattern according to which the first few works of a poet are merely their poetic apprenticeship, and only deserve mention as the primary steps toward the composition of greater works. ${ }^{14} \mathrm{~A}$ second reason is a more practical one: the word "Idea" is not just used as the title of the sequence from 1599 onward, it is also included in the titles of three works published in three consecutive years: Idea. The Shepherds Garland, a pastoral (1593, hereafter SG), Ideas Mirrour (1594, hereafter IM), and Endimion and Phoebe. Ideas Latmus (1595, hereafter E\&P). This has caused considerable confusion, and even distinguished scholars have sometimes mistaken one of the other two works for Drayton's sonnet sequence, Idea, which they have of course not found in the 1593 or 1595 volumes. Finally, much (but, as I insist below, far from all) of $I M$ relies on an unashamedly idealizing, Neoplatonic and Petrarchan language, which strangely enough has sometimes been used as a reason to disparage it as unsophisticated and simplistic.

\section{Drayton and his forbears}

The idealizing dimension of Drayton's poetics ties in with Grundy's description of the Spenserians' attitude to poetry: "The idea of poetic transcendence excites them; they write about

\footnotetext{
13 For that vision of Michael Drayton, see in particular Richard F. Hardin, Michael Drayton and the Passing of Elizabethan England (Lawrence, Manhattan, Wichita: University Press of Kansas, 1961). See also Grundy, The Spenserian Poets.

${ }^{14}$ In The Works of Michael Drayton, ed. J. William Hebel, Kathleen Tillotson and Bernard H. Newdigate, vol.5 (Oxford: Shakespeare Head Press, 1961), 14-15, the editors acknowledge "the strange wild beauty of their style" despite adopting a teleological perspective. See also F.Y. StClair, "Drayton's First Revision of his sonnets," Studies in Philology 36 (1939): 40-59, and Brink, Michael Drayton Revisited, 29-31. Of course, I am not contesting the notion that Drayton's poetic writing might have improved over the years. Rather, I argue that improvement is only part of the picture, and that Ideas Mirrour has much to offer in its own rights, not just as the preliminary version of a betterwritten sonnet sequence.
} 
and not merely in a state of rapture."15 "Drayton," she later adds, "is the true inheritor of Spenser's heroic ideal." ${ }^{16}$ Although Spenser's influence upon Drayton cannot be contested, what is true of Drayton's pastoral does not automatically apply to his sonnets. As far as his first sonnet sequence is concerned, Drayton's model is Sidney, whose Astrophil and Stella is a more likely and more direct influence than Spenser's short sequences in Jan van der Noot's $A$ Theatre for Worldlings (which were, however, included in the publication of his 1591 Complaints), if only because Drayton explicitly and playfully refers to Astrophil and Stella at the end of his prefatory sonnet: "Divine Sir Philip, I avouch thy writ: / I am no pickpurse of another's wit." 17 Quoting line 8 of sonnet 77 in Astrophil and Stella, the couplet does what it says it will not do, ironically positioning Drayton as a follower of Sidney who quotes him to explain that he will not steal from him—very much encapsulating the ambiguities of late sixteenth-century poetic imitation. While Astrophil rejects both the doctrine of inspiration ("Some do I hear of poets' fury tell, / But (God wot) wot not what they mean by it", 1.5-6) and imitation ("I am no pick-purse of another's wit," 1.8), Drayton's speaker foregrounds the imitative process and asserts his reliance on an English rather than on continental models: he will not "filch from Portes [i.e., French poet Philippe Desportes], nor from Petrarch's pen, a fault too common in this later time" (1.11-12). What is more, the line borrowed from Sidney occurs in a poem in which Astrophil claims as a source of inspiration the kiss he stole from Stella. In other words, at the outset of his reputedly Neoplatonic and idealizing sequence, Drayton borrows a line from a sonnet by Sidney in which poetic writing arises from guilty desire.

As both Roche and Kennedy explain, Sidney's sonnet sequence very much follows in the footsteps of Petrarch. More explicitly, it furthers Petrarch's Augustinian perspective by recasting it in the mould of Calvinist morals. In the same way that Petrarch's speaker signals at the opening of his poetic collection that it will address his error (his obsessive love for Laura rather than devout love for God), so Astrophil knows that he should focus on divine matters, but reckons it is "true, that [he] must Stella love" (Astrophil \& Stella 5, 1.14). The frequent critical insistence on Astrophil and Stella's anti-Petrarchism (by which what is usually meant is that the sequence does not promote the divinization of the beloved) tends to disregard the fact that Sidney's and Petrarch's overall perspectives are quite similar-despite different endings: Petrarch's speaker finally pronounces the apotheosis of the Virgin Mary, while Sidney's Astrophil remains hopelessly infatuated and redemption is out of reach. Drayton's way of ironically acknowledging his Sidneian debt is reason enough to reconsider his sequence and his connections with the work of

\footnotetext{
15 Grundy, The Spenserian Poets, 52.

${ }^{16}$ Grundy, 108.

${ }_{17}$ In this paper, I quote Drayton's works from The Works of Michael Drayton, ed. J. William Hebel, Kathleen Tillotson, and Bernard H. Newdigate (hereafter Works), vol.1 (Oxford: Shakespeare Head Press, 1961).
} 
his illustrious forbear. Recent work on Drayton has sought to demonstrate from evidence situated within Ideas Mirrour that it offers a potential criticism of the very notion of idealization it first seems to foster, aligning it with a Petrarchan / Sidneian perspective. ${ }^{18}$ Can such a claim be reconciled with what we know of Drayton's early career?

\section{Drayton's early Ideas: building a career}

In three subsequent years, Drayton published three works whose titles included the word "Idea": Idea. The Shepherds Garland (1593), Ideas Mirrour (1594), and Endimion and Phoebe. Ideas Latmus (1595). While early biographers of Drayton have accounted for this by identifying "Idea" as Anne Goodere and by insisting that the poet was hopelessly in love with her, a more recent study has dismissed this claim as being based on little more than scanty evidence. ${ }^{19}$ The texts themselves display very strong connections on several levels. First, they share a "religious" vocabulary used for the purposes of praise. ${ }^{20}$ In the very first eglog of $S G$, for instance, Rowland (generally understood as Drayton's namesake) says:

Receive my vowes as incense unto thee, My tribute due to thy eternitie. [...]

And let those prayers which I shall make to thee,

Be in thy sight perfumed sacrifice:

Let smokie sighes be pledges of contrition,

For follies past to make my soules submission. (1.41-2, 45-8)

Compare with the first two sonnets of IM:

Reade here (sweet Mayd) the story of my wo, The drery abstracts of my endless cares:

With my lives sorow enterlyned so,

Smok'd with my sighes, and blotted with my teares. [...]

Receave the incense which I offer here

By my strong faith ascending to thy fame,

My zeale, my hope, my vowes, my praise, my prayer,

My soules oblations to thy sacred name. (Amour 1, 1.1-4; 9-12)

Note but my sighes, and thine eyes shall behold,

The Sun-beames smothered with immortall smoke: [...]

Looke thou into my breast, and thou shalt see

Chaste holy vowes for my soules sacrifice: (Amour 2, 1.5-6; 9-10)

\footnotetext{
18 Vuillemin, Le Recueil pétrarquiste, 147-57 and 165-228.

${ }^{19}$ Brink, Michael Drayton Revisited.

${ }^{20}$ Works, vol. V, 6.
} 
The exact same phrase is found in several of these three works: compare for instance $I M$, Amour 23 ("Wonder of heaven, glass of divinitie, [...] Celestiall Image, Load-stone of desire," 1.1 \& 6) and E\&P ("Behold these lyps, the Load-stones of desire," 1. 203). Of course, the poetics of hyperbole that is used in the three works does not suffice to show their connections: Matilda, published the same year as Ideas Mirrour, for instance, includes very similar passages. ${ }^{21}$ There are more direct links between Drayton's three "Ideas" (other than the word the three titles share, that is). One of the prefatory sonnets of $I M$ is addressed to "Rowland" and signed by "Gorbo il fidele," both of whom are shepherd-poets whose voices feature in $S G$, which implies that Rowland is the speaker of IM. In Eglog 9 of $S G$, Rowland pictures himself as Endimion. One of the commendatory sonnets of E\&P confirms that "Rowland" was now Drayton's namesake; even more interestingly, the two works by Drayton to which it refers are $S G$ and $I M$ :

ROULAND, when first I red thy stately rymes,

In Sheepheards weedes, when thou liv'dst unknowne,

Not seene in publique of those former tymes,

But unto Ankor tund'st thy Pype alone,

I then beheld thy chaste Ideas fame,

Put on the wings of thine immortall stile (1.1-6)

According to this account of Drayton's early career, his 1593 pastoral and his 1594 sonnet sequence have brought him fame. This supports the idea that the three works need to be considered together. I now wish to argue that this is because Drayton envisaged the three works as a sort of triptych that would help him promote his career, within an existing framework of career path going from bucolic to epic, or, as David Scott Wilson-Okamura has recently argued, from a low to an elevated style through the mean style. ${ }^{22}$

$S G$, as a pastoral (a type of poem regarded as belonging to the low style), is the first of the three works; $I M$, as a love sonnet sequence, requires the mean style; finally, E\&P, a poem critics have called an epyllion or minor epic concludes the series. ${ }^{23}$ Although the historicity of the

\footnotetext{
21 Works, V, 32.

22 See David Scott Wilson-Okamura, Spenser's International Style (Cambridge: Cambridge University Press, 2013 ), 21. I am indebted to Laetitia Sansonetti for that remark. I do not mean, of course, that Drayton initially envisaged writing three connected works: it seems more likely that the construction of connections between the works happened progressively. Given that $S G$ was published in 1593, IM in 1594, and E\&P in 1595, it is also quite probable that the works were at least partly written simultaneously, which would have made the connections easier to fashion.

${ }^{23}$ See George Puttenham, The Arte of English Poesie Contriued into three Bookes: The first of Poets and Poesie, the second of Proportion, the third of Ornament (London: printed by Richard Field, 1589), 127: "all bymnes and histories, and Tragedies, were written in the high stile: all Comedies and Enterludes and other common Poesies of loues, and such like in the meane stile: all Eglogues and pastorall poems in the low and base stile." For the epyllion, see
} 
category of epyllion is problematic, E\&P would unquestionably be situated higher in a hierarchy of the three works in terms of subject-matter and style. It offers the climax of Drayton's idealizing stance: it is the only poem in which the lover is granted access to a beloved who is, without any possible doubt, divine. The three works deal with love, and their succession corresponds to a form of gradation, or perhaps, to use a cinematographic metaphor, a sort of close-up. In $S G$, love is only one of the topics; it is mostly treated through the words and sighs of Rowland; as in Drayton's pastoral models, Rowland's chastised by an old shepherd, Wynken, who denounces the folly of youth (later, in eclogue seven, Borrill similarly, but unsuccessfully, tries to warn young Batte of the dangers of love). ${ }^{24}$ In $I M$, love is the central topic, but no fulfillment is found. In E\&P, finally, love is truly the union of a mortal with the divine, and the work can unquestionably be read as a spiritual one. ${ }^{25}$ The succession of the works therefore reads as a movement from the earthly to the divine. It also follows a progression from the diversity of the voices in $S G$ to the single narrative voice of E\& P, through the staged voice of the lover in $I M$. Such principle is reflected in the titles, from the multiplicity of the "Garland" through the duality recorded in the term "Mirrour" to the unity of a single place of inspiration, "Latmus." Without daring to commit himself to the epic quite yet, Drayton followed a pattern that underlined the unity of his work and the continuity of his progression. $I M$ therefore occupies a sort of intermediary position in Drayton's three "Ideas." As I will show in my next remarks, this fact can help us understand much about the claims that have been made about it, as well as about the sequence itself, including the notion that it is a Neoplatonic and/or a Petrarchan sequence.

\section{Ideas Mirrour and Neoplatonism: Amour 9, from Medusa to Arethusa}

In an article about Englands Heroicall Epistles, for instance, Barbara C. Ewell avers that

The self-conscious eloquence of Drayton's early poetry clearly aligns him with that Neoplatonic tradition that illumines profound truths through the beauty of poetic surfaces. This aesthetic is glanced at in the title of his sonnet sequence, Ideas Mirrour $[\cdots]$.

\footnotetext{
C.S. Lewis, Sixteenth-Century Poetry Excluding Drama (Oxford: Oxford University Press, 1954), 486-9; Clark Hulse, Metamorphic Verse: The Elizabethan Minor Epic (Princeton: Princeton University Press, 1981), 16-34.

24 As Tillotson and Newdigate indicate (Works, vol.5, 6), the debate between love and old age is a topos of the pastoral that can be found in Theocritus, Virgil, and Mantuan. More recent precedents include Thenol in Spenser's Shepherds Calender (see April eclogue) and the discussion between Geron and Phillisides in the New Arcadia.

25 See Joan Grundy, "Brave translunary things," The Modern Language Review 59, 4 (October 1964): 501-510; Barbara C. Ewell, "Drayton's Endimion and Phoebe: An Allegory of Aesthetics," Explorations in Renaissance Culture 7 (1981): 1526; and Vincent F. Petronella, "Double Ecstasy in Drayton's Endimion and Phoebe," Studies in English Literature 24 (1984): 87-104.
} 
It follows from Ewell's statement that in $I M$, praising the lady is tantamount to praising the Platonic Idea. In such a vision of the sequence, the hyperbolic rhetoric is appropriate because it really refers to a form of transcendence, be it the Platonic or the Neoplatonic Idea. Thomas P. Roche Jr, who was rather skeptical about the influence of Neoplatonism on the Elizabethan sonnet sequence, saw Drayton's sequence as an exception to the theory he developed in Petrarch and the English Sonnet Sequences: "The poet-lover may see his love as a goddess; he may even deify her, but a lady she must be, human, unless one has the explicit aim of writing about divine love under the metaphor of human love as Drayton does."26 The question of Neoplatonism is analyzed in detail in Le Recueil pétrarquiste à l'ère du maniérisme, a study of Drayton's sonnets that contends that the Neoplatonism in IM is a sort of serious game with Neoplatonism rather than a Neoplatonic work per se. ${ }^{27} \mathrm{~A}$ case in point is Amour 9:

Beauty sometime in all her glory crowned, Passing by that cleere fountaine of thine eye: Her sun-shine face there chaunsing to espy, Forgot herselfe, and thought she had been drowned.

And thus whilst Beautie on her beauty gazed, Who then yet living, deemd she had been dying, And yet in death, some hope of life espying, At her own rare perfection so amazed;

Twixt joy and griefe, yet with a smyling frowning, The glorious sun-beames of her eyes bright shining, And shee on her owne destiny divining, Threw in herselfe, to save herselfe by drowning. The Well of Nectar, pav'd with pearle and gold, Where shee remaines for all eyes to behold.

The mythological and philosophical density of this sonnet has been left unaccounted for by scholars so far. ${ }^{28}$ It is probably a response to, elaboration and/or commentary upon a poem which appears in Samuel Daniel's Delia (sonnet XXIX in the first 1592 edition, STC 62432, and sonnet XXXIII in the second 1592 edition, STC 62433): $:^{29}$

\footnotetext{
${ }^{26}$ Roche, Petrarch and the English Sonnet Sequences, 277.

27 Vuillemin, Le Recueil pétrarquiste, 165-228.

28 Tillotson and Newdigate only signal its relationship to a Daniel's Delia XXIX, while only part of the mythological intertext is treated by Le Recueil pétrarquiste, 209-10. The version of Daniel's text I provide is from Delia. Contayning certayne sonnets: vvith the complaint of Rosamond (London : Printed by I. C. for Simon Waterson, 1592), the earlier of the two 1592 editions of the sequence (STC 62432, Sig. E3r).

${ }^{29}$ For the notion that the English sonnet sequences of the 1590 s comment upon one another, see the upcoming chapter by William J. Kennedy, "English Petrarchism: from commentary on poetry to poetry as commentary" in
} 
O why dooth Delia credite so her glasse,

Gazing her beautie deign'd her by the skyes:

And dooth not rather looke on him (alas)

Whose state best shewes the force of murthering eyes.

The broken toppes of loftie trees declare,

The fury of a mercy wanting storme:

And of what force your wounding graces are,

Vppon my selfe you best may finde the forme.

Then leaue your glasse, and gaze your selfe on mee,

That Mirrour shewes what power is in your face:

To viewe your forme too much, may daunger be,

Narcissus chaung'd t'a flowre in such a case.

And you are chaung'd, but not t'a Hiacint;

I feare your eye hath turn'd your hart to flint.

The two poems deal with beauty, the question of the gaze, and the myth of Narcissus. Daniel uses the myth of Narcissus to complain about Delia's indifference, explaining in the third quatrain the danger there is in looking at oneself too much-a warning reminiscent of the moralized interpretation of the myth of Narcissus as a warning against amor sui. The final couplet discards the myth of Hyacinth only to make of Delia a self-harming Medusa, whose gaze turns her own heart to flint.

Comparing the two sonnets reveals Drayton's idealizing stance, as if he was intent on showing that he was concerned with higher matters than his predecessor. It is not the beloved, but "Beautie" personified who looks at herself in a mirror, and the mirror is the beloved's eyes. Drayton adopts Daniel's logic of conflating and/or discarding several myths, and develops it further. While the second quatrain in particular makes the allusion to Narcissus obvious, the very beginning of the poem seems to introduce a cross-gendered version of the myth of Actaeon, as Beauty, like the hunter, comes across a fountain in which she "espies" the beloved. Similarly, in the final couplet, Beauty's only means of saving herself is to fall into herself, that is to become a "Well of Nectar," a fate more akin to Arethusa's than Narcissus's. These mythological allusions serve the main purpose of the sonnet, which is to describe how Beauty finds an incarnation in the beloved, the addressee of the poem. ${ }^{30}$ Some of the mythological allusions indicate the dangers that Beauty (in a reading in Neoplatonic terms, heavenly beauty) is faced with: Beauty/Actaeon is imperiled by its desires, while Beauty/Narcissus runs the risk of self-annihilation by drowningwhich is more or less what happens at the end of the poem. Sonnet 9 reads very much like an

Rémi Vuillemin, Laetitia Sansonetti, Enrica Zanin (eds), The Early Modern English Sonnet: Ever in Motion, The Manchester Spenser (Manchester: Manchester University Press, forthcoming).

${ }^{30}$ By alluding to Arethusa, Drayton might also have had in mind the beginning of Virgil's Eclogue X, in which the call to Arethusa initiates the recounting of unfortunate love stories. 
Ovidian rewriting of Plato's Phaedrus 248c-249c, which accounts for the fall of souls into earthly bodies. As such, unless one discards the Neoplatonic dimension altogether, it exemplifies the accommodation of Ovidianism with Platonic or Neoplatonic doctrines. Beauty is guilty of selflove (which seems hardly possible within a Platonic, or, for that matter, Neoplatonic framework), and that is how she ends up in the eyes of the beloved. What Drayton seems to offer here is a myth of creation of earthly beauty. It is also a playful and somewhat paradoxical account of the beauty of the lady: she is so beautiful that Beauty herself surrenders to her; yet at the same time the lady becomes beautiful precisely because Beauty finds an incarnation in her. The sonnet problematizes the tension between the beloved's beauty and Beauty in the Platonic and Neoplatonic sense. It discloses the fundamental ambiguity of a sonnet sequence that wavers so much between addressing divine Beauty and earthly beauty, the divine Idea and the beloved, that it becomes particularly confusing to the reader. In that sense, some of the major features of $I M$ are strongly Petrarchan ones.

\title{
Ideas Mirrour and Petrarchism: a study of Amour 48
}

$I M$ has been claimed to be both a Petrarchan and a Neoplatonic work. On the one hand, Michael Wentworth, arguing for "Petrarch's triumph" in Drayton's sonnet sequences, sees it as "a predictable and loosely compiled thesaurus of stock attitudes, arguments, and conceits" displaying a form of Petrarchism from which Drayton later departed only to return to it in 1619: ${ }^{31}$

\begin{abstract}
When read as an evolving text culminating in the final 1619 edition, Drayton's Idea [including the 1594 Ideas Mirrour] reveals a frustrated dialectic that incorporates an initial exposition of the traditional Petrarchan scenario (thesis); what is apparently a strident defiance and outright dismissal of such a scenario (antithesis); and, given what proves to be the ineffectual and inauthentic nature of the lover's rejection of tradition, a reversion to, and hence a corroboration of, the formulaic conventions that describe the opening scenario (thesis). ${ }^{32}$
\end{abstract}

Following the teleological perspective that has informed much of the criticism written on Drayton's sonnets, Wentworth contrasts the naïve Petrarchism of Drayton's debut sequence with its rejection in the better-informed later versions, only to finally reach an ironic acceptance of Petrarchism in the final version of Idea in 1619. One of the problems of this approach is that it is

\footnotetext{
${ }^{31}$ Michael Wentworth, "When First I Ended, then I First Began’: Petrarch's Triumph in Michael Drayton's Idea," in Subjects on the World's Stage: Essays on British Literature of the Middle-Ages and the Renaissance, ed. David Allen \& Robert A. White (Newark: University of Delaware Press, 1995) 116-32 [117-18].

${ }^{32}$ Wentworth, 116.
} 
based on a very loose definition of Petrarchism as a "scenario of the long-suffering lover unjustly, and paradoxically, rejected by a disdainful mistress who is alternately praised for her beauty and virtue and condemned for her cruelty." ${ }^{33}$ While this tells part of the story, it does not take into account the potentially deeper implications of Petrarchism, nor the difficulty that circumscribing Petrarchism entails, as seminal works by Heather Dubrow or William J. Kennedy have since done. ${ }^{34}$ In particular, such an approach leaves aside the relationship of IM to Sidney's Astrophil and Stella, and the notion that the reader might not be required to identify with the poet-speaker but, on the contrary, to see his behavior as a negative example, one not to be followed.

Here again, the complexity of Drayton's work will be best shown by focusing on one specific example, in this case one of the most seemingly unequivocal poems in the sequence, Amour 48: ${ }^{35}$

WHO list to praise the dayes delicious lyght, Let him compare it to her heavenly eye: The sun-beames to that lustre of her sight, So may the learned like the similie.

The mornings Crimson to her lyps alike, The sweet of Eden, to her breathes perfume, The fayre Elizia, to her fayrer cheeke, Unto her veynes, the onely Phœnix plume.

The Angels tresses, to her tressed hayre, The Galixia, to her more then white: Praysing the fayrest, compare it to my faire, Still naming her, in naming all delight. So may he grace all these in her alone, Superlative in all comparison.

This sonnet encapsulates the most vibrant praise one could imagine. Like most blazons, it is based on a logic of sedimentation, the accumulation of body parts somehow assembling to compose a portrayal of the beloved. Some blazons written in the same period, such as Sidney's sonnet 9 in Astropbil and Stella, for instance, convey a strong sense of materiality. Not so here: the metaphors refer to things that can be seen, perhaps felt, but which are mostly characterized by their lack of substance. What is more, it is not the eye of the lady that is metaphorized as the sun, her lips that are described as being the color of dawn etc, but the contrary. She is not the tenor of the metaphor, but its vehicle. Such a reversal is in no way specific to Drayton, but it makes the

\footnotetext{
${ }^{33}$ Wentworth, 117.

${ }^{34}$ See note 2.

${ }^{35}$ Here also, I offer a new reading of the sonnet that expands what is shown in Le Recueil pétrarquiste, 172-3 and 222-3.
} 
praise particularly vibrant. ${ }^{36} \mathrm{I}$ would like to argue, however, that this sonnet is much more ambiguous than it would first appear, and that as such, it can be seen as a synecdoche of the whole sequence.

This sonnet is just a page away from one that asserts that the beloved deprives the world of reason. There are also elements in the sonnet itself that encourage one to qualify the notion that this is full-blown praise. To begin with, the praise is left to an absent third person "he." The speaker is not praising the beloved, but giving indications to someone who might wish to do so. The list of "superlative" laudatory phrasings echoes the hyperbolic rhetoric of the first sonnets in the sequence, and the very last line could read as a metatextual reference to the sequence itself. The use of "may" (as opposed to "can") in lines 4 and 13 potentially undermines the hyperbolic rhetoric of the rest of the sonnet, as if to underline the fact that a person wishing to praise the lady may, or may not, adopt it. Finally, and perhaps more importantly, Drayton's sonnet may be a partial rewriting of Petrarch's sonnet $248:^{37}$

Chi vuol veder quantunque pò Natura

e 'l Ciel tra noi, venga a mirar costei, ch'è sola un sol, non pur a li occhi mei, ma al mondo cieco, che vertú non cura;

et venga tosto, perché Morte fura prima i migliori, et lascia star i rei: questa aspettata al regno delli dèi cosa bella mortal passa, et non dura.

Vedrà, s'arriva a tempo, ogni vertute, ogni bellezza, ogni real costume giunti in un corpo con mirabil' tempre:

allor dirà che mie rime son mute, l'ingegno offeso dal soverchio lume; ma se piú tarda, avrà da pianger sempre..$^{38}$

Petrarch's sonnet 248 is one of the poems of the Rime sparse in which the praise of Laura is at its most hyperbolic - but also one in which her mortality is recalled. The capacity for poetry to express beauty is also questioned. The most telling element here is the very beginning of the sonnet: "Who list to praise" sounds very much like "Chi vuol veder," although the verb changes. All through the sixteenth century, Petrarch's language had been analyzed and dismembered.

\footnotetext{
36 See in particular Constable's Diana (1594), First decade, sonnet VII, which constitutes a defense against the accusation of flattering the beloved.

${ }^{37}$ For the following remarks, thanks are due to Enrica Zanin and her upcoming publication on the Italian, French, and English rewritings of Petrarch's sonnet 248, which made me realize that Drayton's Amour 48 could well be one of them.

${ }^{38}$ I quote Petrarch from Canzoniere, ed. Marco Santagata (Milan: Mondadori, 2015).
} 
Tables and indexes in Italian and French editions of Petrarch's poems encouraged one to remember the first lines of Petrarch's poems, and sometimes even to copy his rhymes. In the French sonnets, the first line was very often a way of drawing attention to the Petrarchan source, ${ }^{39}$ a practice which, as far as I am aware, has not yet been documented in the English sonnet, but would deserve to be studied in its own right. Before Drayton, Petrarch's sonnet 248 had been imitated by Thomas Watson and Henry Constable, but also, most importantly for us, by the two poets most likely to have had an influence upon Drayton: Sidney and Spenser. Sidney's version was published in 1591 in Astrophil and Stella, and Spenser's was republished in the same year.

Sidney's sonnet, "Who will in fairest book of nature know" (A\&S 71), is highly laudatory, accenting Stella's perfection and how her beauty can lead one to virtue-but its ending, one of the best-known lines in the Sidneian canon, shows that this is not enough for Astrophil: "But ah, desire still cries: 'Give me some food'." Despite the opportunity that is offered to him, the lover still falls prey to his guilty desire. Spenser's poem, "who lists to see, what ever nature, art" (sonnet 5 from "The Ruines of Rome," in the 1591 Complaints), a translation from Du Bellay, is about Rome and its ruins. Rome replaces Laura, and the reminder of mortality is applied to the melancholy sight of Renaissance Rome, long after its past glory, and not so long after its 1527 sack. If Drayton did indeed draw inspiration from Petrarch's sonnet, he retained its beginning and its praising stance, which he developed until the end, but cast aside the rest, most importantly the reference to Nature and the reminder of the beloved's mortality. Although many sixteenthcentury European rewritings of sonnet 248 focus on hyperbolic praise, especially in Italy, Petrarch's poem initially aims at showing the vanity of earthly beauty. What's more, Sidney's and Spenser's sonnets (those Drayton is most likely to have had in mind) consist in emphasizing respectively the fact that the sight of beauty will not appease the lover's desire, and the ephemeral character of Rome. All of this contributes to making Drayton's poem ambiguous. An interpretation of the poem as a revelation of the speaker's excessive and artificial praise is possible, especially if one reads the sequence as a whole.

\section{From idealization to idolatry}

\footnotetext{
${ }^{39}$ See Olivier Millet, "Du Bellay et Pétrarque, autour de l'Olive," in Les Poètes français de la Renaissance et Pétrarque, ed. Jean Balsamo (Geneva: Droz, 2004), 253-266 and Cécile Alduy, Politique des "Amours». Poétique et genèse d'un genre français nouveau (1544-1560) (Geneva: Droz, 2007), 362.
} 
The following remarks rely on the analyses formulated in Le Recueil pétrarquiste à l'ère $d u$ manierisme. IM is built upon networks of topoi that progressively associate, dissociate, and come loose. The first half of the collection, taken as a whole, deifies the beloved using, among other things, the imperial imagery that was also used to praise Elizabeth (see for instance the conceits of the Eagle in Amour 3, of the Phoenix in amour 6, or the allusions to Vesta in Amour 5), and recounts the spiritual ascension of the lover. However, the status of both speaker-lover and beloved progressively evolves. While the beloved is first metaphorized as the sun, she is then referred to as the moon, and finally as a malevolent planet in Amour 47. The triumphant flight of the "Eagle-birds of love" (a probable allusion to The Courtier, Amour 3) is quickly replaced by the figure of Icarus (Amour 22); in Amour 37, the speaker is "imprisond in the ayre" (1.12), as his attempt at elevation is thwarted by his despair. ${ }^{40}$

This general movement is complicated by sonnets that contrast with their immediate contexts: while the beginning of the sequence tends to idealize the beloved and magnify the speaker's venture, Amour 15, for example, offers a fantasy of control not very far from rape ("Ile binde her then with my torne-tressed haire, / And racke her with a thousand holy wishes, / Then on a place prepared for her there, / Ile execute her with a thousand kisses. / Thus will I crucifie my cruell shee, / Thus Ile plague her which so hath plagued mee." 1.13-18). ${ }^{41}$ Such poems undermine the speaker's credibility as a would-be philosopher-poet ready to contemplate heavenly beauty. Conversely, the end of the sequence, in which the evil influence of the beloved bears on a speaker incapable to elevate himself, includes sonnets, such as Amour 48, that are even more laudatory than those at the beginning of the sequence, at least at first glance. A case in point is Amour 46, whose final couplet is consistent with a reading of the sequence as Neoplatonic: “O purest merror, wherein men may see / The lively Image of Divinitie.” However, it is difficult to identify the addressee of that poem, which starts as follows: "Sweet secrecie, what tongue can tell thy worth?" This is not a customary way of addressing a beloved, even a Petrarchan one. Ina Schabert convincingly relates this sonnet to a passage in Hoby's translation of The Courtier which is about heavenly beauty. ${ }^{42}$ The "Sweet secrecie" of the first line is therefore not the beloved, but heavenly beauty. This seems to corroborate Roche's idea that the sequence deals with divine love under the guise of earthly love-but such a reading does not really work for other sonnets in the sequence, as my analyses show hereinabove. The problem is to find a

\footnotetext{
${ }^{40}$ For the allusion to the Courtier, see Vuillemin, Le Recueil pétrarquiste, 186.

${ }^{41}$ Amour 15 and Amour 16 are the only poems in the sequence which are not sonnets in the strictest sense, since they are eighteen lines long (perhaps following the model of Thomas Watson's 1582 Hekatompathia).

42 Ina Schabert, "Michael Drayton, Ideas Mirrour and Idea, Sonette 1594-1619. Vollständige und kommentierte Textausgäbe” (PhD Diss., Ludwig-Maximilians-Universität zu München, 1969), 120-1. Schabert's work is the most thorough commented edition of Ideas Mirrour extant. Unfortunately, it has largely remained unnoticed by nonGerman critics, undoubtedly for reasons of language and of availability.
} 
way of understanding the Neoplatonic background of the sequence without making of IM a sort of poetic illustration or transposition of Neoplatonic theses, which it clearly is not.

A relevant way of solving the problem is to acknowledge the Petrarchan dimension of the sequence: the speaker-lover's infatuation is an error, and as a consequence, he is not necessarily trustworthy as a speaker. In other words, the speaker might wish to reach the contemplation of heavenly beauty, but he is not able to do so, as his attempts at elevation fail in the course of the sequence, at least partly on account of his inability to abandon the body, or, in more specifically Neoplatonic terms, to stop seeing with the eyes of the body to see with the eyes of the soul. ${ }^{43}$ The end of IM seems to dissociate the "evil planet," the lady's beauty in which the speaker's senses are imprisoned, from "Sweet secrecie," i.e. heavenly beauty, which the speaker is unable to reach. ${ }^{44}$ Such an interpretation complicates the too often presupposed relationship between Neoplatonism and Petrarchism. In IM, they complement each other (perhaps more so than stated in Le Recueil pétrarquiste). While the speaker is highly ambitious, he remains a sinner like Sidney's Astrophil; his "erected wit" is weighed down by his "infected will." ${ }^{45}$ In that interpretation, Drayton's speaker might mistake his perceptions for a higher truth, a risk posed by imagination in the early modern period according to Rayna Kalas: "the imagination was always at risk of becoming idolatrous by mistaking an image in the mind for truth itself, or, alternately, by fixating on sensory perceptions as ends unto themselves, rather than physical ephemera that serves the faculty of reason"- - a danger also signaled by Sidney and more explicitly by William Scott in his recently rediscovered The Modell of Poesy. ${ }^{46}$ To make of IM a work about idolatry, however, remains problematic. Both Sidney and Scott's works were informed by their Calvinism, and though little is known about Drayton's faith, his main biographer infers from his works that he must have been rather moderate in religious matters and possibly sympathetic to Catholics. ${ }^{47}$ What is more, Drayton is not very likely to have condemned an idealized vision of poetry at that

\footnotetext{
${ }^{43}$ See Sir Thomas Hoby, The courtyer of Count Baldessar Castilio dinided into foure bookes. Very necessary and profitable for yonge gentilmen and gentilwomen abiding in court, palaice or place, done into English by Thomas Hoby (London: imprinted by William Seres, 1561), Sigs. Xxiv-Xxiir ${ }^{\mathrm{r}}$.

${ }^{44}$ The above interpretation of Ideas Mirrour is conditional. Crucially, it requires a reading of Ideas Mirrour as a whole, as opposed to the possibility of only reading certain sonnets from it, or that of extracting poems from their context to put them to other uses. This possibility will be not developed here. More importantly for the purpose of this work, the above interpretation also ascribes to Ideas Mirrour a metapoetic dimension.

${ }^{45}$ See Sidney's The Defence of Poesy, 10, in Sidney's 'The Defence of Poesy' and Selected Renaissance Literary Criticism, ed. Gavin Alexander (London: Penguin Books, 2004), 3-54.

46 See Rayna Kalas, Frame, Glass, Verse - The Technology of Poetic Invention in the English Renaissance (Ithaca: Cornell University Press, 2007), 2. See William Scott, The Model of Poesy [1599], ed. Gavin Alexander (Cambridge: Cambridge University Press, 2013), 41-2.

${ }^{47}$ See Bernard H. Newdigate, Michael Drayton and his Circle (Oxford: Shakespeare Head Press, 1961), 214-218.
} 
stage of his career, and his Neoplatonic stance in E\&P has been convincingly demonstrated. ${ }^{48}$ How are we therefore to reconcile the guilty speaker of IM and the exaltation of poetry in E\& ? ?

\section{High aspirations}

Drayton's three "Ideas" display high aspirations. SG includes the first exposition of Drayton's poetic ambitions: as Jean Brink remarks, $S G$ can be seen as a "poetic manifesto," with the apotheosis of poetry in Eclog 5, formulated in the hyperbolic style which will also be found in $I M$ and E\& P. The latter work has been described as an allegory of poetic inspiration. ${ }^{49}$ The three works seem to include a metapoetic dimension, and they possibly have connections on that level as well: $S G$ is composed of nine books (rather than the ten books of Virgil's Eclogues) to match the number of the muses, as the subtitle of the work shows (Rowlands Sacrifice to the Nine Muses). In IM, Amour 8 (a sonnet which would soon be mocked and parodied), the speaker announces he has found his own muse, a tenth, as if the sonnet sequence allowed him to complete the unfinished work of SG. Finally, the three works deal, in different manners, with the themes of elevation and of astronomy. If there is indeed a form of gradation between the three works, then the interest of emphasizing the overall Petrarchan, rather than just Neoplatonic, dimension of $I M$ becomes obvious. While poetic elevation is projected in $S G$ and achieved by Endimion in E\&P, it is problematized in IM. In Petrarch's Rime sparse, the speaker's "error" is not just his infatuation for Laura: at a more metaphorical level, it is also his quest for earthly fame rather than divine elevation. Similarly, the speaker in $I M$ attempts poetic elevation, but is revealed to be incapable of it, or unable to rise above the level of the earthly.

In $I M$, it is quite probably the speaker's own nature that precludes his spiritual ascension. But as is also underlined in Le Recueil pétrarquiste, what the speaker mostly complains about, as Petrarchan lovers often do, is the fact that the beloved either refuses to look at him or that her gaze harms him. ${ }^{50}$ In either case, her gaze is not a benevolent one. As opposed to such lack of consideration, the narrative of E\&P is made possible by the attention the moon goddess bestows on the young Shepherd, triggering the process of elevation and Endimion's celestial journey. A full passage from Petronella's article explaining the process that leads to the Neoplatonic separation of body and soul is worth quoting here:

\footnotetext{
48 See Vincent F. Petronella, "Double Ecstasy in Drayton's Endimion and Phoebe," Studies in English Literature 24 (1984): 87-104.

49 See Grundy, "Brave Translunary Things," 505-7 and Barbara C. Ewell, "Drayton's Endimion and Phoebe: An Allegory of Aesthetics," Explorations in Renaissance Culture 7 (1981): 15-26.

50 Vuillemin, Le Recueil pétrarquiste, 190-4.
} 
The Neoplatonists thought of this process as one implemented by the gods whose overflow (emanatio) of bountifulness descends to the level of mortal beings; this in turn leads to a "vivifying rapture or conversion (called by Ficino conversio, raptio, or vivificatio) whereby the lower beings [are] drawn back to heaven and [rejoin] the gods (remeatio)." At the center of this triadic rhythm of emanatio-raptio-remeatio is the ecstatic experience that sparks the return to and union with the One Itself. And it is lovemadness in particular that makes the return possible. But we must not forget that what initiates the process is a god or gods showering a mortal with divine gifts. The divine or supernatural world enter that of the mortal (emanatio); the mortal becomes enraptured (raptio) and anticipates the refreshing newness of a return (remeatio) to the divine level. ${ }^{51}$

From a Neoplatonic perspective, what might prevent the speaker in IM from pursuing his ascension is the lack of the benevolent intervention of a divine figure such as Phoebe. ${ }^{52}$ This itself might be cause for the insufficient qualities of the lover, as the process of aiming for the contemplation of heavenly beauty is what leads to self-improvement and transformation. In other words, the failures of the speaker in Ideas Mirrour might result from the fact that his endeavor is ignored and/or held in contempt. Drayton's speaker might not be like the speaker of the Rime sparse: his problem might not be that he is corrupt, but rather that the lack of recognition prevents him from achieving his ambitious aims. As one can imagine, such a reading easily leads to the question of Drayton's relationship to his patrons.

\section{Drayton, patronage, and the Sidney family}

Drayton's three "Ideas" are connected to the Sidney family in one way or another, as Jean Brink's work has shown. ${ }^{53}$ Although the model of $S G$ is primarily Spenser's The Shepheardes Calender rather than Sidney's Arcadia, Eglog 4 includes an elegy on the death Elphin, "the God of Poesie," quite obviously Sir Philip Sidney (1.90-143). Eglog 6 praises Pandora (1.55-162), a namesake for Mary Sidney, then Mary Herbert, Countess of Pembroke, Sidney's sister and, as we now know, a major figure of the period's poetry. ${ }^{54}$ This praise comes just after a "lament for the

\footnotetext{
${ }^{51}$ Petronella, "Double Ecstasy in Drayton's Endimion and Phoebe," 89.

52 Petronella points out that the notion of emanatio appears in The Courtier, a text Drayton is much more likely to have had access to (for instance in Hoby's translation) than Ficino's works. See "Double Ecstasy in Drayton's Endimion and Phoebe," 89.

${ }^{53}$ Michael Drayton Revisited, 7-9. This paragraph is indebted to her work.

54 See Works V, p.10 and Michael Drayton Revisited, 7-9. On the central role of Mary Sidney in English letters, see for instance Gavin Alexander, Writing after Sidney: The literary response to Sir Philip Sidney, 1586-1640 (Oxford: Oxford university press, 2006), chapter 3; Patricia Pender, "The Ghost and the Machine in the Sidney Family Corpus," Studies in English Literature 51,1 (Winter 2011): 65-85.
} 
decline of virtuous patronage." ${ }^{, 5}$ The liminary sonnet that ties $S G$ and $I M$ together, signed by "Gorbo il fidele," also refers to the Countess of Pembroke as Pandora and mentions "Arcadian swaines": "Ankor tryumph, upon whose blessed shore, / The sacred Muses solemnize thy name: / Where the Arcadian Swaines with rytes adore / Pandoras poesy, and her living fame." (1.1-4). There might be other references to the Sidneys inside the sequence, but the only indisputable ones are in the very last sonnet, Amour 51:

GOE you my lynes, Embassadors of love, With my harts trybute to her conquering eyes, From whence, if you one teare of pitty move For all my woes, that onely shall suffise.

When you Minerva in the sunne behold, At her perfection stand you then and gaze, Where, in the compasse of a Marygold, Meridianis sits within a maze.

And let Invention of her beauty vaunt, When Dorus sings his sweet Pamelas love, And tell the Gods, Mars is predominant, Seated with Sol, and weares Minervas glove. And tell the world, that in the world there is A heaven on earth, on earth no heaven but this.

Line 10 is an obvious reference to the characters of the Arcadia, confirming the pastoral framework established by the prefatory sonnet, a framework that the second half of the sequence had very much left aside: Pamela and Musidorus in the guise of Dorus the shepherd (the same Musidorus who initially admonishes his friend Pyrocles and warns him against love). Tillotson and Newdigate, among other conjectures, recall that "Minerva" was used by Howell, Nashe, Fitzgeffrey, and Drayton himself in $S G(E g l o g$ 6, 1.86) to refer to Mary Sidney, while Philip was called Phoebus (i.e., Sol) by Nashe. ${ }^{56}$ Jean Robertson has argued that "Meridianis" was the anagram of Mary Sidney (Mari Sidnei), and therefore another allusion to her. ${ }^{57}$ However we choose to read this rather confusing sonnet, the presence of the Sidneys, brother and sister, is felt, either as poetic or as social benefactors.

Amour 51's position and meaning pose a series of problems. As the last poem of the collection, it constitutes a threshold both inside and outside of it; it accompanies the reader toward the end of the book (the author adjoined no work to IM, contrary to the subsequent Idea, which was first published with Englands Heroicall Epistles in 1599) and holds particular importance

\footnotetext{
${ }^{55}$ See Michael Drayton Revisited, 28 and SG, Eglog 6, 1.25-53.

56 Works V, 17.

${ }^{57}$ See Jean Robertson, "Drayton and the Countess of Pembroke," Review of English Studies 16 (1965): 49.
} 
as it frames the whole. Accordingly, it starts with an envoi, recalling the motif of flight which was so prevalent in the first half of the collection, especially in Amour 3. While Amour 18 proclaimed: "I passe not for Minerva, nor Astrea, / But ever call upon divine Idea" (1.13-14), the speaker here hopes that his poems will rise to the level of Minerva. But what concerns me here is mostly the overall tone and the ending of the poem. While the speaker does not renounce love, he is not presenting himself as an unrepentant sinner either. The beloved has not played the role of an intermediary between earth and the divine (like Beatrice), but she has not been replaced (like Laura) by the Virgin Mary either. Rather than concluding the story of the speaker's endeavors, the couplet purports to open a new cycle of elevation. The "heaven on earth" (1.14) might be the beloved, but it is more likely to be the activity of the poet-a poet who might not be able to reach the contemplation of heavenly beauty, but who can at least try. Drayton seems to have considered the Sidneys as more than a combination of literary models and potential patrons: they correspond to a fantasized ideal of poetry and of a poetic life built by Drayton in his three "Ideas."

Very soon after the publication of IM, Drayton dedicated his Matilda (1594) to Mary Sidney's cousin, Lucy Harington, who was shortly to become Lucy Russell, Countess of Bedford. She was also the dedicatee of E\&P in 1595. The contrast between these two works (one written before Lucy's marriage, one after) is interesting: while Matilda exposes the dangers of lust in the character of King John, E\&P recounts an allegorical tale of sublime and spiritual love. Brink sees Drayton's Phoebe as a metaphorical figuration of Lucy, and states that “[o]n one level, Drayton intended Endimion and Phoebe to compliment Lucy by suggesting that his chaste admiration for her beauty had inspired his verse," and that "Drayton ... makes Lucy the source of inspiration and the subject of that inspiration." 58 It seems that $I M$ occupies a sort of intermediary stage not just in the writing of Drayton's three "Ideas", but also in his bids for patronage. While SG was his starting point, $I M$ problematizes his situation as a poet whose excellence only awaits the blessing of a prestigious patron to unfold and to reach higher spheres, and E\&P presents the reader with the outcome of such patronage - probably a more recommendable way of begging for patronage than implying, although rather obliquely, that the failings of the speaker/Petrarchan lover were to be attributed to a lack of consideration for him. Although this reading would render IM quite clumsy in social terms, this would be consistent with the most recent studies of Drayton as a poet "noticeably hostile to distinctions of class," who however "only has himself to blame" for his failure to obtain patronage. ${ }^{59}$

\footnotetext{
${ }^{58}$ Michael Drayton Revisited, 32-3.

${ }^{59}$ See Michael Drayton Revisited, 5 and Andrew Hadfield, "Michael Drayton's Brilliant Career," Proceedings of the British Academy 125 (2003): 119-147.
} 


\section{Coda}

$I M$ has been dismissed on several grounds: its hyperboles, its phraseology, regarded as repetitive or even childish, its 'conventionality,' or too strong Petrarchism. By reconsidering the Petrarchism and the oft assumed Neoplatonic dimension of the sequence, I have claimed that $I M$ is not the simplistic work it has been said to be and even that it reaches a strong degree of complexity. It does not use human love as an allegory of divine love, but uses Neoplatonic references (some of them probably taken from Hoby's translation of The Courtier) playfully to show the failures of the lover-speaker while still exhibiting Drayton's poetic ideal. It has common ground with Petrarch's Rime sparse, in which the love of the lover for the beloved is a moral and spiritual problem. It is a fundamentally ambiguous collection, and such ambiguity resides in the fundamental question of the ethos of the speaker, a problem already apparent in Sidney's Astrophil and Stella, and too often ignored in lesser-known sonnet sequences. To rephrase Roche's observation a little differently, it seems that we still tend to mistake the lovers of early modern sonnet sequences for the Romantic lyric ' $\mathrm{T}$ ' to which we are now more accustomed in poetry. ${ }^{60}$

The example of Drayton's IM does indeed provide a good testing ground for Roche's theory. It exemplifies the intricacy of poetic, moral, spiritual, and social questions. By reconsidering IM in the context of Drayton's early career, I have shown the connections between a moral and spiritual Petrarchan model on the one hand, and social issues of class and patronage on the other hand. Rather than undermining or contradicting Roche's ideas, I hope to have shown that they need to be qualified. Roche pictures English sonneteering as a staunchly Augustinian enterprise. Although he is probably right to insist on the pervasiveness in England of Petrarch's project in the Rime sparse (it makes sense in a Reformed, and especially a Calvinist context, and the interpretation of Petrarch as a proto-Protestant poet is the most common one in sixteenth-century English printed sources ${ }^{61}$ ), his contention that love sonnet sequences and spiritual sonnet sequences perform the same act in two different ways seems too one-sided. The speakers of late-Elizabethan sonnets may be negative moral examples to an extent, but seeing all of the sequences as primarily didactic is probably overstretching that explanation: Roche failed to acknowledge that they could be both ambiguous and playful, and tended to leave aside much of their context of publication. His Petrarch and the English Sonnet Sequences paved the way for a better

\footnotetext{
${ }^{60}$ Roche writes that we tend to see the speakers of love sonnet sequences as similar to Goethe's Werther, and therefore that we believe we are supposed to sympathize with them. See Petrarch and the English Sonnet Sequences, viii.

${ }^{61}$ See Boswell and Braden, Petrarch's English Laurels, 4.
} 
understanding of the sequences; it seems fair to further elaborate on his vision of them and to give Drayton's first sonnet sequence the place it deserves in the English poetic production of the late Elizabethan era. To a certain extent, it seems that Roche has made the sequences too literally Petrarchan, in the sense of seeing them similar to Petrarch's Rime sparse, in response to a more general tendency to reduce Petrarchism to a series of set attitudes and clichés. Illustrating neither of those two extremes, the example of Drayton's IM shows that the complexity of English Petrarchism is worth investigating. 